\title{
Assessing the Risk of Post-earthquake Fire and Presenting Risk Reduction Strategies in Qazvin and Markazi Provinces
}

\author{
Mahsa Shariat Alavi ${ }^{1} \oplus$, Shahin Shapouri ${ }^{1} \mathbb{1}$ \\ Date of submission: 22 Jul. 2020 Date of acceptance: 22 Oct. 2020
}

\begin{abstract}
INTRODUCTION: The location of Qazvin and Markazi provinces in high-seismicity regions has increased the probability of earthquake occurrence in these provinces. One of the most serious crises that threaten Qazvin and Markazi provinces is the post-earthquake fire which will be very probable considering the potential hazards. The present study aimed to identify the factors affecting the post-earthquake fire and present some strategies for pre-and post-earthquake preparedness in Qazvin and Markazi provinces.

METHODS: In this descriptive-analytical study, the maps were produced using the Geographic Information System (GIS), and data collection sources were books, articles, and documents. Three main maps of risk, vulnerability, and crisis were prepared, and the analyses were performed by SWOT (strengths, weaknesses, opportunities, and threats) table. Thereafter, some practical strategies and policies were presented to achieve the intended goals. Strategies were developed for four programs to mitigate risk likelihood and vulnerability, manage fire, and reconstruct, along with development.

FINDINGS: As evidenced by the obtained, the dispersion of some man-made factors, such as power transmission lines, gas stations, and high-risk industries, increases the likelihood of postearthquake fires in both provinces. Furthermore, such geographical factors as scattered vegetation and location in arid climates increase the probability of fire spread. The final map of the crisis demonstrated that fires are more likely to occur in the center of Qazvin province and the north of Markazi province.

CONCLUSION: Based on the results of the present study, the first step in regional planning and policy-making for the mitigation of fire hazards must be based on crisis maps and in harmony with subsequent hazards and damages. In this regard, to mitigate the risk of post-earthquake in these two provinces, the following measures are suggested: increasing safety in infrastructure, networks, facilities, industrial estates, and high-risk industries.

Keywords: Geographic Information System; Planning; Qazvin and Markazi Provinces; Postearthquake Fire.
\end{abstract}

Original Article

How to cite this article: Shariat Alavi M, Shapouri S. Assessing the Risk of Post-earthquake Fire and Presenting Risk Reduction Strategies in Qazvin and Markazi Provinces. Sci J Rescue Relief 2020; 12(4): 254-69.

\section{Introduction}

$\mathrm{N}$ atural disasters have caused great human and financial damages across the globe, and most of these disasters, such as earthquakes, are preventable. Earthquakes, as one of the most dangerous disasters, can bring about indirect effects, such as fire ignition (1). Due to the unpredictability of earthquakes, the knowledge of these secondary incidents and the provision of practical solutions for their management is among the most effective measures. Small fires which are often triggered by earthquakes can sometimes turn into widespread and destructive fires causing severe damages to people's lives and property due to such factors as the type and density of buildings, wind conditions, as well as loss of water resources and firefighting capabilities (2).

1- MA, architecture engineering, post-disaster reconstruction at Shahid Beheshti university, Tehran, Iran

Correspondence to: Mahsa Shariat Alavi, Email: mahsa.shariat.1372@gmail.com 


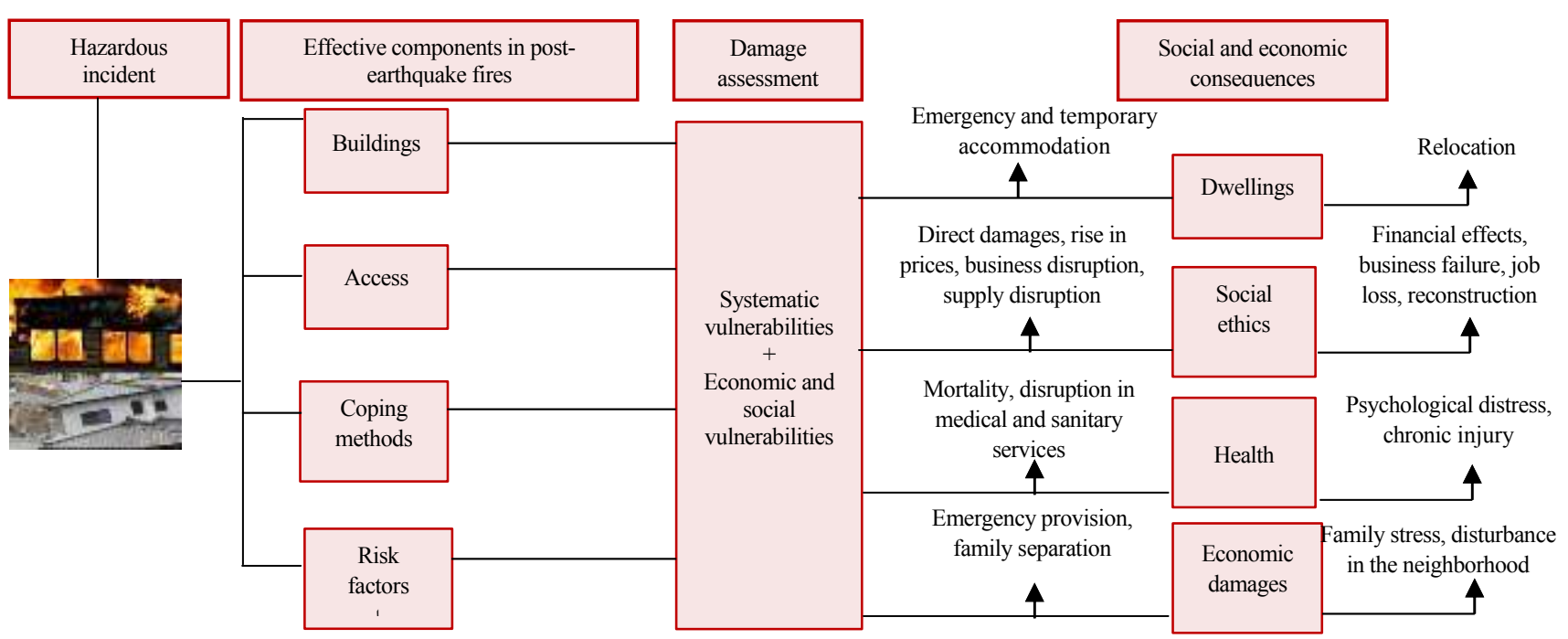

Diagram 1. Vulnerability to post-earthquake fire (3)

So far, no focused study has been conducted using a management approach to identify the effective criteria to improve the conditions of vulnerable regions in the country; moreover, the performed studies have merely presented onefactor maps. Therefore, in order to evaluate the risk of fire following earthquakes, the present study aimed to identify the factors affecting the probability of occurrence, vulnerability, coping and reconstruction methods; moreover, it strived to present the effective measures to achieve the research objectives. Diagram 1 displays the algorithm of the general relationship between postearthquake fire and its subsequent consequences.

Post-earthquake fire has unique characteristics, the first of which is simultaneous fire ignition in different parts of the city. The second feature of these fires is their expansion potential since firefighting facilities and access extinguisher agents are limited due to the destruction of access roads and other buildings. Secondly, the large number of these fires leads to the shortage of firefighters and facilities. Moreover, successive and uncontrollable explosions will fuel this expansion if gas service systems are set on fire (3).

Combustion and the magnitude of fire are affected by such human factors as construction materials, building use, architectural and structural design of a building, residents' reaction time, the distance between the fire and rescue service, and firefighting capabilities, as well as natural factors, such as wind direction and speed. Post-earthquake fire is a process encompassing earthquake occurrence, combustion, detection, response, and suppression (4). Fires in laboratories, industries, and chemical warehouses are chemical fires fueled by light heaters or chemical substances (5).

The pipelines containing flammable liquids, such as gasoline, tanks, and refineries are exposed to potential hazards, and these combustible liquids are more likely to penetrate or exit the pipe or tanks due to wear, tear, and corrosion of the pipes (6). Diagram 2 illustrates the algorithm of direct and indirect damages caused by earthquakes in combustible organizations, especially petrochemical

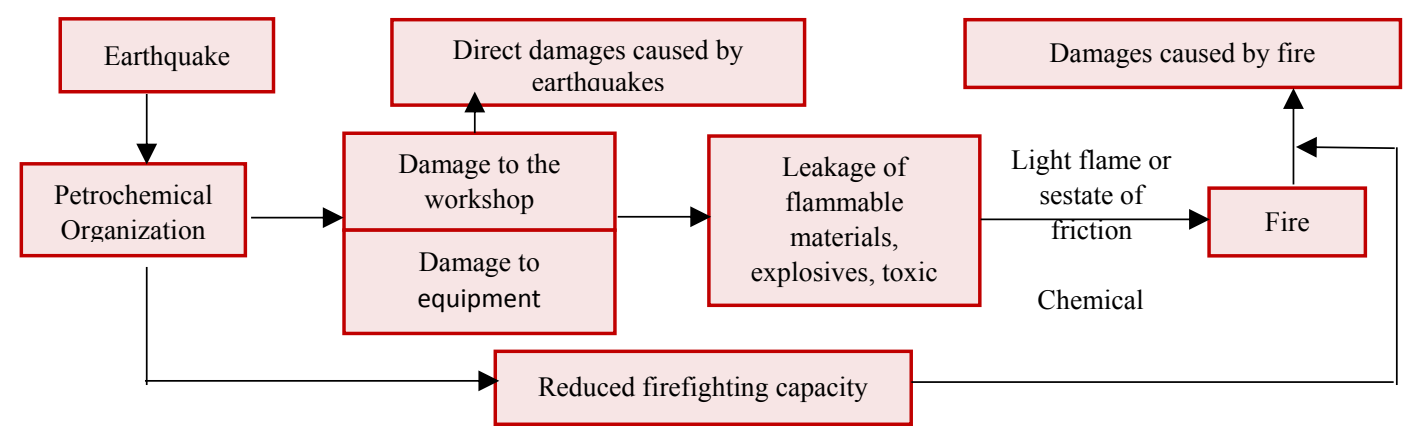

Diagram 2. Mechanisms used by petrochemical companies in post-earthquake fire (7) 


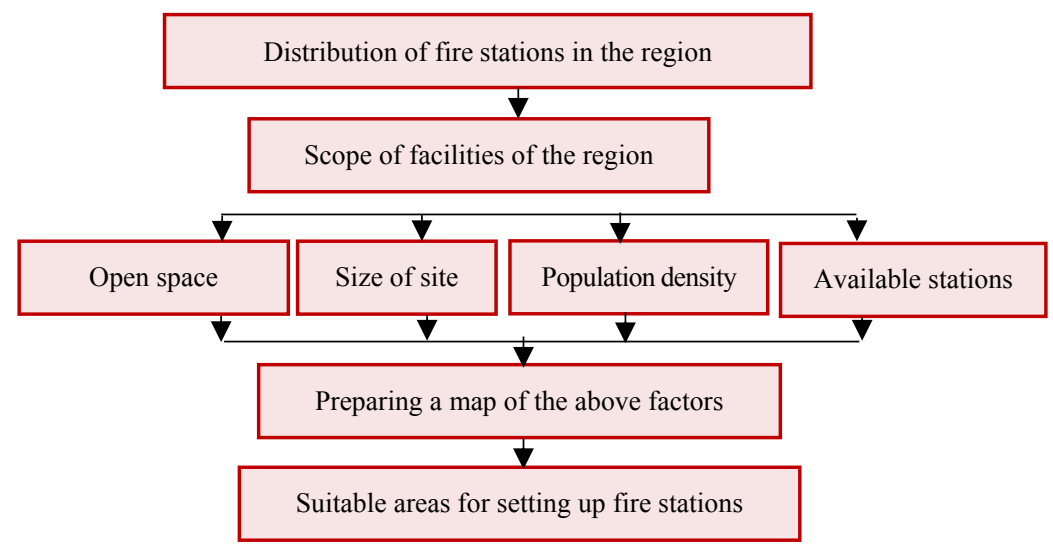

Diagram 3. Location-allocation of firefighting units (8)

organization. According to this figure, apart from earthquake damages, leakage, chemical reactions, and other factors can cause even more severe human and financial damages, compared to the ground motion itself.

Broken urban gas pipelines are another important cause of the occurrence and spread of post-earthquake fires. Hazards in gas pipelines include main gas transmission pipelines, boost stations, and gas supply networks. Fire stations, as the custodian of firefighting and relief, play a peculiar role in controlling fires. Distance from fire stations significantly affects the vulnerability of a specific region (8). Diagram 3 depicts the factors affecting the location-allocation of firefighting units. According to this figure, the condition of the stations should be checked and optimized according to such factors as population density.

One of the major goals is the prevention of fire from starting and spreading. Table 1 summarizes the history of the post-earthquake fire in the world to shed light on the adverse effects of this incident. It is worth noting that based on statistics; damages caused by the post-earthquake fire in the United States were much more severe than ground motions (9).

Mizuno et al. (1978) developed the first postearthquake ignition model based on postearthquake fire statistics in Japan (11). Zolfaghari et al. presented an analytical model based on some factors, such as the destruction of structural

Table 1. Examples of post-earthquake fires in the world $(9,10)$

\section{Earthquake}

April 18, 1906 MW 7.9

San Francisco, USA

September 1, 1923, MW7.9 Kanto, Japan

January 17, 1994, MW 6.7

Northridge, USA

January 17, 1995, MW 6.9

Kobe, Japan

\section{Cause of post-earthquake fire}

Broken water pipelines

Very high and unusual temperatures Improper use of explosives to create a fire barrier

Fire in wooden buildings due to overturning Gas stoves while cooking lunch Hot and dry winds (at a speed of 21 meters per second)

Formation of an electric arc due to a short circuit Breaking the gas pipe due to PGA acceleration = $1.8 \mathrm{~g}$

Damage to the water distribution system

Broken valves, and power, gas, and water pipelines Lack of access to suitable facilities for firefighting due to lack of traffic jams and extensive destruction
3000 people were killed

$\$ 524$ million (in 1906) property damage

225,000 homeless in San Francisco 28,000 buildings destroyed ( $80 \%$ due to fire)

140,000 people were killed

Destruction of 447,000 houses

57 people were killed Damage to 40,000 buildings Direct damages estimated at 40 billion dollars

6,400 people were killed Damage to 250,000 buildings

Direct damages estimated at 200 billion dollars 
elements, non-structural elements of buildings, building density (building area and the number of floors), and building usage (12). Esposito (2011) developed the geographical database according to the physical data and functional characteristics of the gas system. Yildiz and Karaman presented a physical model for the estimation of the number of fires inside the building and their location for urban areas. Some other factors, such as construction equipment system (gas and electricity), high-risk devices (gas heater and stove), and low-risk devices (e.g., computer and television), were considered, in addition to the modified Mercalli intensity and the maximum acceleration of the earth.

The studies conducted on post-earthquake fires indicate that these investigations have been mostly non-analytical and based on the statistics of postearthquake fires in Japan and the US. Due to shortcomings of disaster statistics in Iran, a distinction has not been made between primary damages (caused by earthquakes) and the secondary (post-earthquake fires) ones. Therefore, there is no accurate statistics or scientific study on the damage caused by secondary outcomes of earthquakes.

The available reports are limited to the news announced by some organizations, such as the Red Crescent and the fire department. Among these reports, we can refer to those released in some earthquakes, including fires caused by the explosive rupture of domestic gas pipelines and the burning of wooden houses in Rudbar and Manjil. It is noteworthy that most of the earthquakes in Iran have occurred in low-risk regions and times in terms of industries and refineries. Therefore, widespread fires have not been reported in these areas, and the majority of them have been occasional home and building fires.

Qazvin and Markazi provinces were selected for the present study due to the existence of highrisk industries, refineries, and active faults. In the event of an earthquake in these two provinces (especially industrial cities, such as Arak due to the density of high-risk industries in an area), the damages caused by fire may be much more severe than the direct damage of the earthquake itself. Therefore, it is necessary to conduct a study to identify the criteria and provide practical solutions for these areas.

The majority of the studies in the field of risk reduction planning have been carried out at the city level, and there is a dearth of studies performed at a regional scale. Therefore, the present study strived to present a model for the development and implementation of a strategic plan to reduce vulnerability and preparedness for this risk by the development of four programs that provide strategies for the reduction of risk and vulnerability, as well as coping and reconstruction methods, in two provinces of Qazvin and Markazi at a regional scale.

\section{Methods}

This applied research was conducted based on a descriptive-analytical method and used library studies to collect the required data. To this end, books, valid articles, and documents (especially the preparation plan of Qazvin and Markazi provinces) were studied in order to become more familiar with the region. The general algorithm of the present research consists of four main stages which are referred to in the following:

fires 1 . The first program: planning to reduce the possibility of post-earthquake

2. The second program: planning to present effective solutions to mitigate the adverse effects of post-earthquake fires

3. The third program: planning to prepare the community to deal with fires following earthquakes

4. The fourth program: reconstruction plan along with sustainable development and reducing the risk of this incident in the region

Firstly, the factors required for each program were compiled in the DSD (Data Structure Diagram) table using the studies performed and experts' opinions. Human and natural (geographical) factors, each of which includes a series of sub-factors, were introduced. For each of the factors, in the GIS (Geographic information system), some maps were designed with two functions of distance and density in the form of raster layers with the ability to perform operations on them. The internal scores of the layers were determined within the range of $0-10$ based on their priority and impact. A score of 10 signifies high vulnerability, while 0 means no or low vulnerability.

Each of the factors was assigned a weight using the opinions of professors and $\mathrm{PhD}$ students of the Department of Accidents and Reconstruction, Faculty of Architecture and Urban Planning, Shahid Beheshti University. 
The statistical population of specialists included four professors, six PhD students and graduates, and a number of specialists from the Red Crescent and fire department. Finally, a crisis map was presented by adapting the raster layers in the RGIS environment.

After analyzing the maps and studying the documents, the SWOT (Strengths, Weaknesses, Opportunities, and Threats) table was developed to identify the strengths, weaknesses, opportunities, and threats of the four programs used in the current research. Finally, the tables of SWOT matrix analysis, as well as compatibility and strategic analysis, yielded policies and measures in four areas of planning, defensive, offensive, and crisis in the study area.

The research questionnaires need to be valid and reliable. The validity of the questionnaire was confirmed using the expertise of professors, the confirmation of statistical community (scientific and experimental experts), and comparison with previously performed studies. The reliability of this questionnaire was also confirmed considering the predominance of factors that do not change much over time. It is worth noting that depending on professors' opinions, the weight values of 0-5 were assigned to the solutions considered for each program to recognize their importance.

\section{Findings}

The majority of environmental planning programs are based on gathering information about the research setting and its natural features, such as climate, topography, and rainfall, as well as physical characteristics, such as environmental, agricultural, and industrial potentials. As illustrated in Map 1, the dominant wind direction is between north and northeast for $30 \mathrm{~m}$ height in Qazvin province, while the prevailing wind direction is from southwest and west in Markazi province.

The wind speed is moderate in the north of Qazvin province and the southwest of Markazi province, while in other parts of these two provinces, the wind speed is higher towards the center of these provinces. It should be noted that all weather information was gathered from Synoptic weather stations in Qazvin and Markazi provinces in 2016. As depicted in Map 2, these two provinces lack forest cover and scattered vegetation is dominant. Map 3 demonstrates that in Qazvin province, the temperature gradually increases from the northern parts of Qazvin Plain toward the southern parts, while in Markazi province, the temperature decreases by moving from north to south.

Qazvin lacks any source of natural gas and gas refinery, and electricity generation takes place in a power plant. On the other hand, Markazi province as the largest producer of gasoline in Iran is the home to an oil refinery. In terms of industrial factories in Qazvin province, Alborz city (50.2\%) has the greatest contribution. In Markazi province, Arak, Saveh, and Zarandieh have the highest frequency in terms of the number of industrial estates among other cities in the province (15). In Map 4, it seems that the shortest distance from the gas pipelines is in the center of Qazvin province, as well as northeast and south of Markazi province. According to Map 5, high- risk industries, all industrial units which use flammable solids, liquids, or gases as raw materials or contain large and small chemical, cellulosic, and petroleum warehouses, are mostly

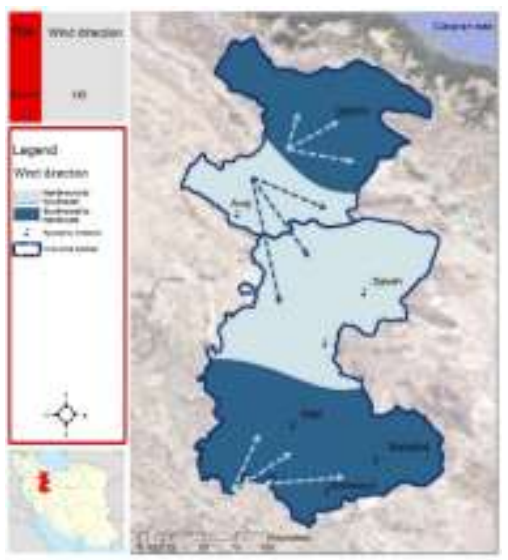

Map 1. Wind direction

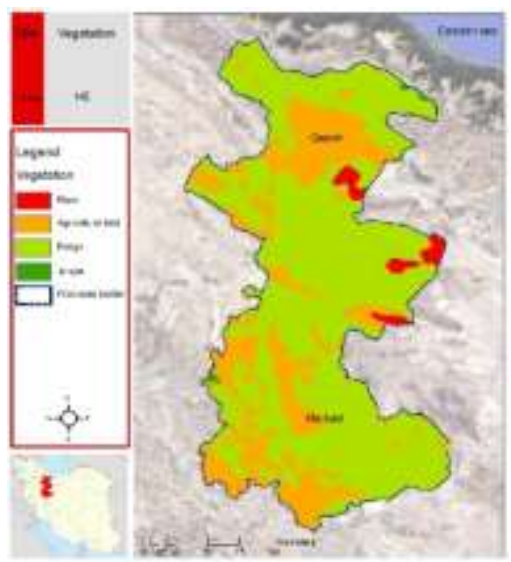

Map 2. Vegetation

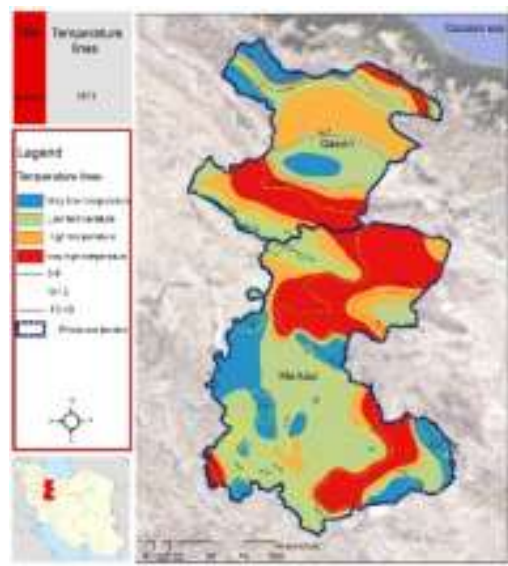

Map 3. Zoning of isothermal lines 


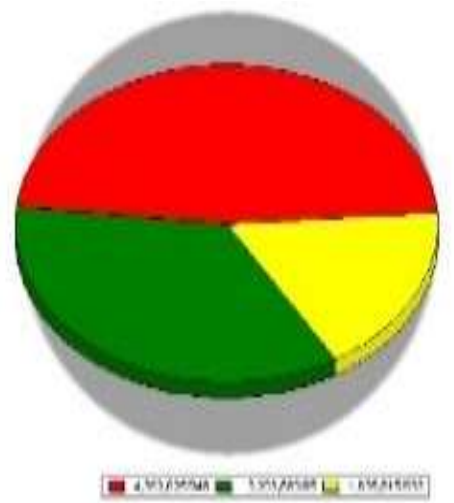

Diagram 4. Area of main roads vulnerable regions

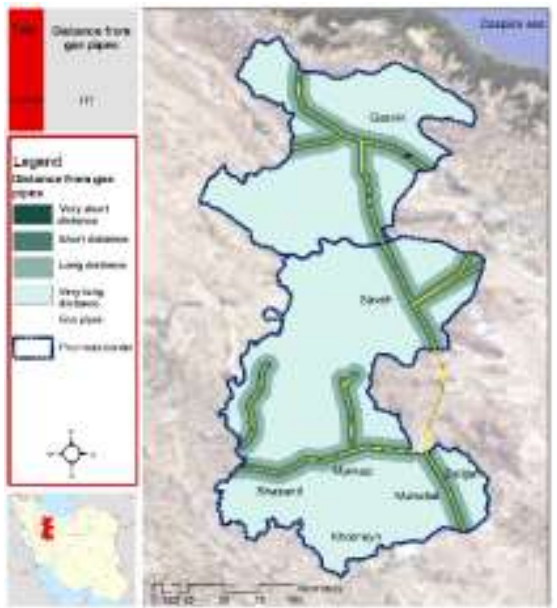

Map 4. Distance from gas transmission pipelines located in the center of Qazvin province, while they are evenly distributed in other regions of the two provinces.

In the first program which aimed to prevent risks, the factors affecting the creation of hazards were compiled in the DSD table in order to find the logical association and the required map. Table 2 demonstrates some of these factors which were obtained by studying related documents and articles.

As displayed in Table 3, the factors affecting the occurrence of hazards are divided into two

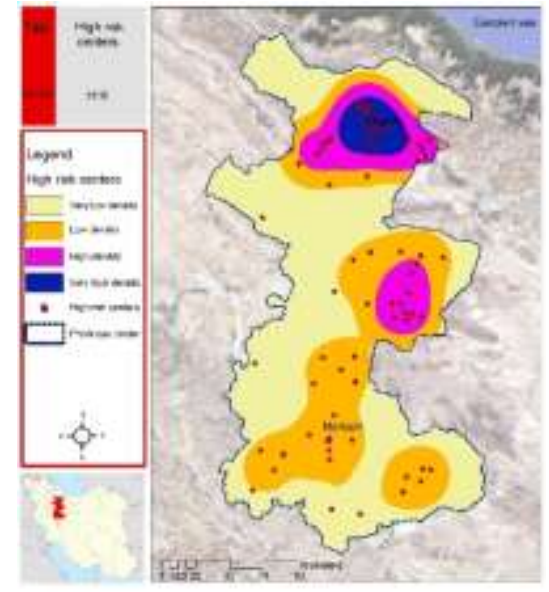

Map 5. Density of high-risk industries

Table 2. Identification of risk factors and vulnerability (Tables 3 and 4)

\begin{tabular}{|c|c|c|c|c|c|}
\hline \multirow{2}{*}{ Number } & \multirow{2}{*}{ Source } & \multicolumn{2}{|r|}{ Risk factors } & \multicolumn{2}{|c|}{ Vulnerability factors } \\
\hline & & Criterion & Sub-criterion & Criterion & Sub-criterion \\
\hline & $\begin{array}{l}\text { Davidson, } \\
\text { Scawthorn }\end{array}$ & Human & $\begin{array}{l}\text { Power boost station, Power and gas } \\
\text { transmission pipelines }\end{array}$ & Physical & $\begin{array}{l}\text { Access networks, } \\
\text { water pipelines }\end{array}$ \\
\hline 1 & $\begin{array}{l}(2008) \\
(16)\end{array}$ & Geographical & $\begin{array}{c}\text { Precipitation, vegetation, slope, } \\
\text { evaporation }\end{array}$ & Relief & $\begin{array}{l}\text { Fire stations } \\
\text { Health centers }\end{array}$ \\
\hline 2 & $\begin{array}{l}\text { Lee, Wang, } \\
\text { (2013) } \\
\quad(7)\end{array}$ & $\begin{array}{c}\text { Human } \\
\text { Geographical }\end{array}$ & $\begin{array}{c}\text { High-risk industries, industrial cities, } \\
\text { and factories } \\
\text { Active faults, temperature }\end{array}$ & Physical & $\begin{array}{l}\text { Network of water } \\
\text { transmission } \\
\text { pipelines }\end{array}$ \\
\hline 3 & $\begin{array}{l}\text { Scawthorn } \\
\text { (2012) }\end{array}$ & Human & $\begin{array}{l}\text { Gas transmission pipelines and } \\
\text { petroleum products, such as gasoline } \\
\text { Power transmission pipelines and } \\
\text { power amplification }\end{array}$ & $\begin{array}{l}\text { Physical } \\
\text { Relief }\end{array}$ & $\begin{array}{c}\text { Network of water } \\
\text { transmission } \\
\text { pipelines } \\
\text { Fire stations }\end{array}$ \\
\hline 4 & $\begin{array}{l}\text { Baktash, } \\
\text { Givehchi, } \\
(2017)\end{array}$ & Geographical & $\begin{array}{c}\text { Gas boost station, gas transmission } \\
\text { pipelines, oil and electricity } \\
\text { Wind speed and direction, active } \\
\text { faults }\end{array}$ & $\begin{array}{l}\text { Economic } \\
\text { Social }\end{array}$ & Urban population \\
\hline
\end{tabular}


Table 3. DSD table of risk factors

\begin{tabular}{|c|c|c|c|c|c|c|}
\hline \multicolumn{2}{|c|}{ Risk factors } & $\begin{array}{l}\text { Effective } \\
\text { factors }\end{array}$ & $\begin{array}{l}\text { Impact } \\
\text { factor }\end{array}$ & Logical association & Title of map & $\begin{array}{l}\text { Map } \\
\text { Number }\end{array}$ \\
\hline \multirow{11}{*}{$\begin{array}{l}\text { Environme } \\
\text { ntal }\end{array}$} & Water & Rain & 3 & $\begin{array}{l}\text { More rain in the region increase the } \\
\text { likelihood of fire intensification. }\end{array}$ & Isohyetal line map & $\mathrm{H} 1$ \\
\hline & \multirow{2}{*}{ Wind } & $\begin{array}{l}\text { Wind } \\
\text { direction }\end{array}$ & 5 & $\begin{array}{l}\text { Wind direction determines the direction } \\
\text { of fire spread. }\end{array}$ & $\begin{array}{l}\text { Wind direction } \\
\text { map }\end{array}$ & $\mathrm{H} 2$ \\
\hline & & Wind speed & 7 & $\begin{array}{l}\text { The higher the wind speed, the more } \\
\text { likely the fire is to spread. }\end{array}$ & Wind speed map & $\mathrm{H} 3$ \\
\hline & \multirow{5}{*}{ Earth } & Active faults & 10 & $\begin{array}{l}\text { The likelihood of fire occurrence } \\
\text { increases with a greater distance from } \\
\text { active faults. }\end{array}$ & $\begin{array}{l}\text { Distance from } \\
\text { active faults }\end{array}$ & $\mathrm{H} 4$ \\
\hline & & Vegetation & 6 & $\begin{array}{l}\text { The likelihood of fire occurrence } \\
\text { increases in regions with low vegetation. }\end{array}$ & Vegetation map & H5 \\
\hline & & $\begin{array}{l}\text { Mountain and } \\
\text { plain range }\end{array}$ & 4 & $\begin{array}{l}\text { The fire is more likely to spread in } \\
\text { plains. }\end{array}$ & $\begin{array}{l}\text { Map of the } \\
\text { mountain and } \\
\text { plain area }\end{array}$ & H6 \\
\hline & & Slope & 4 & $\begin{array}{l}\text { The fire is less likely to spread in regions } \\
\text { with steep slopes. }\end{array}$ & Slope map & $\mathrm{H} 7$ \\
\hline & & Topography & 4 & $\begin{array}{l}\text { The fire is more likely to spread in } \\
\text { regions with plain topography }\end{array}$ & Topography map & H8 \\
\hline & \multirow{3}{*}{ Heat and cold } & Evaporation & 2 & $\begin{array}{l}\text { The higher the evaporation rate, the } \\
\text { more likely the fire is to intensify. }\end{array}$ & $\begin{array}{l}\text { Map of } \\
\text { evaporation lines }\end{array}$ & H9 \\
\hline & & Climate & 6 & $\begin{array}{l}\text { The higher the temperature, the more } \\
\text { intense the fire. }\end{array}$ & $\begin{array}{l}\text { Climate zoning } \\
\text { map }\end{array}$ & H10 \\
\hline & & Heat & 7 & $\begin{array}{l}\text { The fire is more likely to intensify in } \\
\text { drier climates. }\end{array}$ & $\begin{array}{l}\text { Map of isothermal } \\
\text { lines }\end{array}$ & H11 \\
\hline \multirow{10}{*}{ Human } & \multirow[t]{7}{*}{ Industry } & $\begin{array}{l}\text { Gas boost } \\
\text { station }\end{array}$ & 8 & $\begin{array}{c}\text { The likelihood and severity of the hazard } \\
\text { increases as we approach the electrical } \\
\text { panels. }\end{array}$ & $\begin{array}{l}\text { Distance between } \\
\text { power boost } \\
\text { stations }\end{array}$ & H12 \\
\hline & & $\begin{array}{l}\text { Power boost } \\
\text { station }\end{array}$ & 8 & $\begin{array}{l}\text { The likelihood of fire occurrence } \\
\text { decreases as we keep a distance from } \\
\text { power boost station. }\end{array}$ & $\begin{array}{l}\text { Distance from gas } \\
\text { boost stations }\end{array}$ & H13 \\
\hline & & $\begin{array}{l}\text { Storage place } \\
\text { of petroleum } \\
\text { products }\end{array}$ & 9 & $\begin{array}{l}\text { The likelihood of fire occurrence } \\
\text { increases with densely stored petroleum } \\
\text { products. }\end{array}$ & $\begin{array}{l}\text { Density of storage } \\
\text { place of } \\
\text { petroleum } \\
\text { products }\end{array}$ & H14 \\
\hline & & Gas station & 7 & $\begin{array}{l}\text { The likelihood of fire occurrence } \\
\text { decreases as we keep a distance from } \\
\text { gas stations. }\end{array}$ & $\begin{array}{l}\text { Distance from gas } \\
\text { stations }\end{array}$ & H15 \\
\hline & & $\begin{array}{l}\text { Industrial } \\
\text { estates }\end{array}$ & 9 & $\begin{array}{l}\text { The greater the distance between } \\
\text { industrial estates, the greater the } \\
\text { likelihood of fire. }\end{array}$ & $\begin{array}{l}\text { Distance from } \\
\text { industrial estates }\end{array}$ & H16 \\
\hline & & Refineries & 2 & $\begin{array}{l}\text { The likelihood of fire occurrence } \\
\text { increases as we approach refineries. }\end{array}$ & $\begin{array}{l}\text { Distance from oil } \\
\text { and gas refineries }\end{array}$ & H17 \\
\hline & & $\begin{array}{l}\text { High-risk } \\
\text { industries }\end{array}$ & 7 & $\begin{array}{l}\text { The probability of casualties increases } \\
\text { with the higher density of high-risk } \\
\text { centers in the region. }\end{array}$ & $\begin{array}{l}\text { Density of high- } \\
\text { risk centers }\end{array}$ & H18 \\
\hline & \multirow{3}{*}{$\begin{array}{l}\text { Energy } \\
\text { sources }\end{array}$} & Gas pipelines & 10 & $\begin{array}{l}\text { The shorter distance between the gas } \\
\text { pipelines increases the risk of fire. }\end{array}$ & $\begin{array}{l}\text { Distance between } \\
\text { gas pipelines }\end{array}$ & H19 \\
\hline & & Oil pipelines & 9 & $\begin{array}{l}\text { The longer distance between oil } \\
\text { pipelines decreases the risk of fire. }\end{array}$ & $\begin{array}{l}\text { Distance between } \\
\text { oil pipelines }\end{array}$ & $\mathrm{H} 20$ \\
\hline & & Power lines & 10 & $\begin{array}{l}\text { The longer distance between power lines } \\
\text { decreases the risk of fire }\end{array}$ & $\begin{array}{l}\text { Distance between } \\
\text { power lines }\end{array}$ & $\mathrm{H} 21$ \\
\hline
\end{tabular}


categories: human and environmental. Human factors can be assigned to two areas of industry and infrastructure, and environmental factors can be classified into four sections: water, wind, land, as well as heat and cold. Each of these factors has subcategories for which the degree of impact, logical connection, and the required map has been developed. The effect of each factor was considered based on a questionnaire filled out by experts. For instance, the gas pipeline network as a factor resulting in hazards has an impact factor of 10. Therefore, this factor has a profound effect on starting the post-earthquake fire. Consequently, it is stated that the probability and severity of the hazard decrease as the distance of the gas pipelines from the area increases. Therefore, it seems necessary to prepare the map of the distance from the gas pipeline network in the first program.

The maps which were required in the first program and obtained by the DSD table were made in GIS software. For example, Map 6 illustrates the distance from the power lines which are spread throughout Qazvin and Markazi, except for the southwestern parts of Qazvin and the northwest of Markazi. In order to produce a map of the areas prone to fire, the maps obtained from geographical and human factors affecting the occurrence of post-earthquake fire were integrated taking into account their coefficient of importance, and finally, we achieved the risk map of post-earthquake fire.

According to Map 7, central areas and a part of southeastern Qazvin are most prone to fire. Moreover, some parts of the central, northeastern, and southwestern Markazi are the high-risk

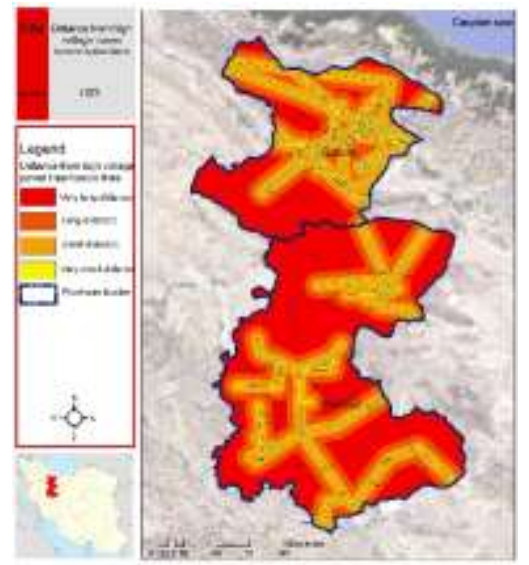

Map 6. Distance from high-voltage power transmission lines regions. In general, the cities of Qazvin, Alborz, Buin Zahra, Saveh, and Shazand are more prone to post-earthquake fire, compared to other cities.

A risk map enables us to identify these problems and resolve or mitigate them using the SWOT table and presenting effective strategies and policies. Table 4 was prepared by the authors of the article and reviewed and approved by the professors of the group who are experienced in the field of the incident and crisis management.

Upon the analysis of the SWOT table, some policies and measures were developed in all four areas of planning, offensive, defensive, and crisis so as to reduce the risk of this hazard. For example, in Map 8, two maps of wind speed and high-risk centers were integrated to identify areas where high-risk centers with high wind speed are concentrated. The utilization of natural resources and the use of windbreaks in designated locations are among the implemented measures in the planning field.

The second program aimed to reduce vulnerability to hazards and develop some strategies to mitigate the effects of postearthquake fires. Various human, economic, security, and relief issues have been considered in determining the vulnerability of the study area. Table 5 was prepared to identify vulnerabilities and obtain the maps which are needed for this program.

Since one of the effects of fire is the reduction of horizontal visibility and disruption of transporttation, it is necessary to map the vulnerability of roads. Another benefit of a road network vulnerability map is the identification of inefficient and hazardous routes. As displayed in

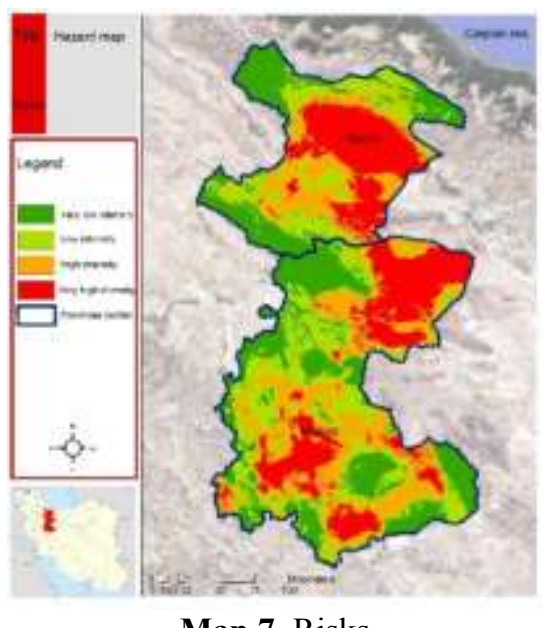

Map 7. Risks 
Table 4. Strengths, weaknesses, opportunities, and threats table of the first program (risk factors)

Risk factors

$\begin{array}{ccc}\text { Wisk factors } & \text { Strength (S) } \\ \text { S1: Rainfall in most } \\ \text { seasons in the north of } \\ \text { Qazvin province } \\ \text { prevents e fire } \\ \text { intensification. }\end{array}$

S2: Low wind speed in densely populated cities

Wind Wind speed of Qazvin and Markazi results in reduced fire spread.

S4: Low temperature in

Heat

and

Heat

cold the highlands of the two provinces

S8: The location of away from dense urban areas prevents fire from reaching these areas

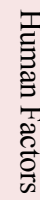

Power $\quad$ S9: Use of rugged cables lines routes

Physical $\begin{array}{r}\text { Boost } \\ \text { station }\end{array}$

S5: Most facilities are equipped with a seismic Weakness (W) Opportunity (O) Threat (T) many industrial centers
W1: Further spread of fires in cities located in areas with low rainfall

W3: Rapid spread of fire in Avaj city due to very high wind speed

W10: High temperature in most regions of the study area

W16: Failure to observe fire safety in settlements which leads to fire

W25: Degraded cable covers

W11: Degradation of gas and power station facilities causes poor performance
O1: The possibility of reduced occurrence of fires due to high humidity in rainy areas in the north of the province

O4: Ability to use methods to reduce wind speed near high-risk centers

O8: Prevent the construction of centers with the possibility of an explosion in areas with high temperatures

O15: Possibility of training employees on fire prevention methods in industrial estates

O21: Ability to strengthen the protective cover of power lines sensor to prevent fires.
O9: Possibility to strengthen the safety of existing facilities
T1: The possibility of fire due to the gradual decrease in rainfall in the province

T2: Increased probability of fire ignition if it coincides with the wind

T11: Gradual rise in air temperature

T18: The possibility of fire spread due to negligence in the location-allocation of these industrial estates

\section{T23: Possibility of} overturning of transmission towers due to earthquake

T13: Possibility of disruption in gas and electricity stations in case of an earthquake
Diagram 4, the largest area is for A-class roads depicted in red. Therefore, there is less vulnerability in these areas. Map 9 shows that the cities of Qazvin, Saveh, and Arak have the highest density of commercial centers, which greatly increases the risk of vulnerability.

The final vulnerability map was produced by obtaining all the required maps of Table 5 (vulnerability factors) and merging all the layers. According to Map 10, the regions with high

$\begin{array}{ccc}\begin{array}{c}\text { Strategy } \\ \text { Policy } \\ \text { Implementation }\end{array} & \begin{array}{c}\text { Utilization of natural resources } \\ \text { Control of wind energy }\end{array} \\ \text { Use of windbreaks around high-risk centers } \\ \begin{array}{c}\text { By illuminating the layer of high-risk centers } \\ \text { on the wind speed layer, we can identify the } \\ \text { areas where these centers are exposed to high- } \\ \text { speed winds. In so doing, windbreaks can be } \\ \text { considered for these areas to control wind } \\ \text { speed. }\end{array}\end{array}$

Map 8. Use of windbreaks in the vicinity of high-risk centers 
Table 5. DSD (vulnerability factors)

\begin{tabular}{|c|c|c|c|c|c|}
\hline Number & $\begin{array}{l}\text { Effective } \\
\text { factors }\end{array}$ & $\begin{array}{l}\text { Impact } \\
\text { factor }\end{array}$ & Logical association & Title of the map & Number \\
\hline \multirow{3}{*}{ Physical } & Dams & 4 & $\begin{array}{l}\text { The vulnerability decreases as we } \\
\text { keep a distance from dams. }\end{array}$ & $\begin{array}{l}\text { Distance from } \\
\text { dams }\end{array}$ & V1 \\
\hline & Transportation & 6 & $\begin{array}{l}\text { The vulnerability decreases as we } \\
\text { keep a distance from the main roads. }\end{array}$ & $\begin{array}{l}\text { Distance from } \\
\text { the road }\end{array}$ & $\mathrm{V} 2$ \\
\hline & $\begin{array}{l}\text { Water } \\
\text { transmission } \\
\text { networks }\end{array}$ & 8 & $\begin{array}{c}\text { The vulnerability decreases with } \\
\text { higher density of water transmittion } \\
\text { networks. }\end{array}$ & $\begin{array}{l}\text { Density of water } \\
\text { pipes }\end{array}$ & V3 \\
\hline \multirow[t]{2}{*}{ Relief } & Fire department & 9 & $\begin{array}{l}\text { The vulnerability decreases with } \\
\text { shorter distance from fire } \\
\text { departments. }\end{array}$ & $\begin{array}{l}\text { Distance from } \\
\text { fire department }\end{array}$ & V4 \\
\hline & Hospital & 8 & $\begin{array}{l}\text { The vulnerability decreases with a } \\
\text { shorter distance from medical centers. }\end{array}$ & $\begin{array}{l}\text { Distance from } \\
\text { medical centers }\end{array}$ & V5 \\
\hline \multirow[t]{2}{*}{ Environmental } & River & 3 & $\begin{array}{c}\text { Density of rivers and springs } \\
\text { decreases the likelihood of } \\
\text { vulnerability. }\end{array}$ & $\begin{array}{l}\text { Density of rivers } \\
\text { and springs }\end{array}$ & V6 \\
\hline & Lake & 4 & $\begin{array}{l}\text { The vulnerability decreases with a } \\
\text { shorter distance from the lakes. }\end{array}$ & $\begin{array}{l}\text { Distance from } \\
\text { the lake }\end{array}$ & V7 \\
\hline \multirow{3}{*}{ Social } & City proper & 8 & $\begin{array}{l}\text { The vulnerability decreases as we } \\
\text { keep a distance from city proper. }\end{array}$ & city proper & V8 \\
\hline & $\begin{array}{l}\text { Urban } \\
\text { population }\end{array}$ & 6 & $\begin{array}{l}\text { The higher the urban population } \\
\text { density, the higher the vulnerability. }\end{array}$ & $\begin{array}{l}\text { Urban population } \\
\text { density }\end{array}$ & V9 \\
\hline & $\begin{array}{l}\text { Rural } \\
\text { population }\end{array}$ & 5 & $\begin{array}{l}\text { The higher the rural population } \\
\text { density, the higher the vulnerability. }\end{array}$ & $\begin{array}{l}\text { Rural population } \\
\text { density }\end{array}$ & V10 \\
\hline Economic & $\begin{array}{l}\text { Business } \\
\text { centers }\end{array}$ & 7 & $\begin{array}{l}\text { The lower the density of shopping } \\
\text { malls, the greater the likelihood of } \\
\text { vulnerability. }\end{array}$ & $\begin{array}{l}\text { Distance from } \\
\text { important } \\
\text { shopping centers }\end{array}$ & V11 \\
\hline
\end{tabular}

vulnerability are located in areas that can be justified according to the DSD table since in these areas, vulnerability factors, including physical, environmental, social, and economic factors, as well as crisis management, have occurred with greater intensity (higher weights). This map signifies that the northern and central parts of Qazvin province and the southwestern part of

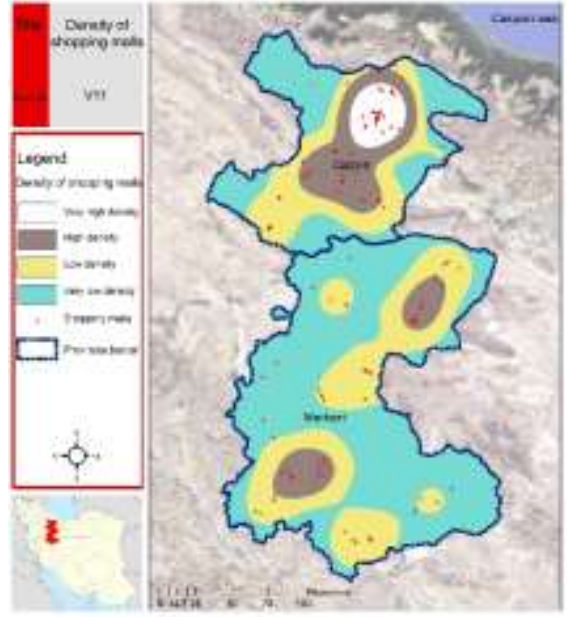

Map 9. Density of shopping malls
Markazi provinces are most vulnerable to post earthquake-fire. The level of vulnerability is high or very high in Qazvin, Takestan, Buin Zahra, Arak, and Shazand.

Table 6 examines the strengths, weaknesses, opportunities, and threats of the factors affecting post-earthquake ignition vulnerability. For example, in the section of relief factors, the

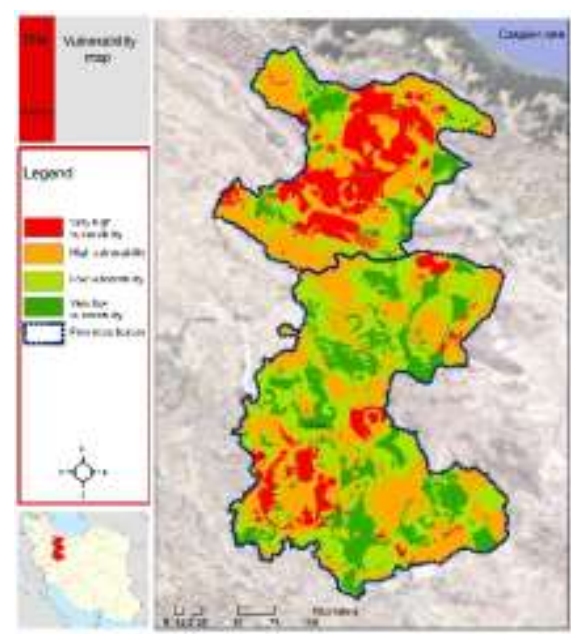

Map 10. Final Vulnerability 
Table 6. Analysis of strengths, weaknesses, opportunities, and threats of the second program (vulnerability factors) Risk factors Strength (S)

\section{Weakness (W) \\ W5: Lack of \\ emergency equipment in some water sources for pumping and transport \\ W7: Absence of fire department in the southeast of Markazi province Opportunity $(\mathrm{O})$ \\ O6: Density of water pipelines in high-risk areas
O7: Ability to use the fire services of neighboring provinces

Water
Physical transmission networks

Relief Fire
department

S4: Dispersion of fire stations in the area

Rivers,

Environmental springs, and lakes

Human
resources

Social resources

Economic
S8: Revitalization of lakes in two provinces

\section{S11: Having the} necessary manpower to reduce vulnerability and community preparedness

\section{S14: Extensive} agriculture in two provinces
W11: Poor land and pasture program

$$
\begin{aligned}
& \text { W15: Lack of } \\
& \text { sufficient } \\
& \text { experience in } \\
& \text { reducing fire } \\
& \text { vulnerability }
\end{aligned}
$$

\section{W19: Use of large amounts of water resources in agriculture} rehabilitation
O10: Distribution of river water and other water sources

O13: Establishment of non-governmental groups to pursue risk reduction and preparedness in the community

O18: The possibility of expanding and increasing agricultural productivity through the training of new methods and the provision of facilities
Threat (T)

T3: High vulnerability in areas with low water network density.

T4: Vulnerability of firefighters exposed to contamination and smoke from fires

T6: Possibility of drought spread if it continues

T9: Lack of necessary preparation of people and endangering the health of others

T12: Regional threat to water crisis if old agricultural methods continue to be used dispersion of fire stations in the region, the absence of fire departments in the southeast of Markazi province, the possibility of using fire services of neighboring provinces, and the vulnerability of firefighters exposed to contamination and smoke from fire were regarded as strength, weakness, opportunity, and threat, respectively.

After reviewing Table 6 and obtaining the matrix of SWOT and compatibility tables, some strategies were presented to prevent vulnerability to hazardous incidents. According to Map 11, one of the strategies achieved in the planning field is

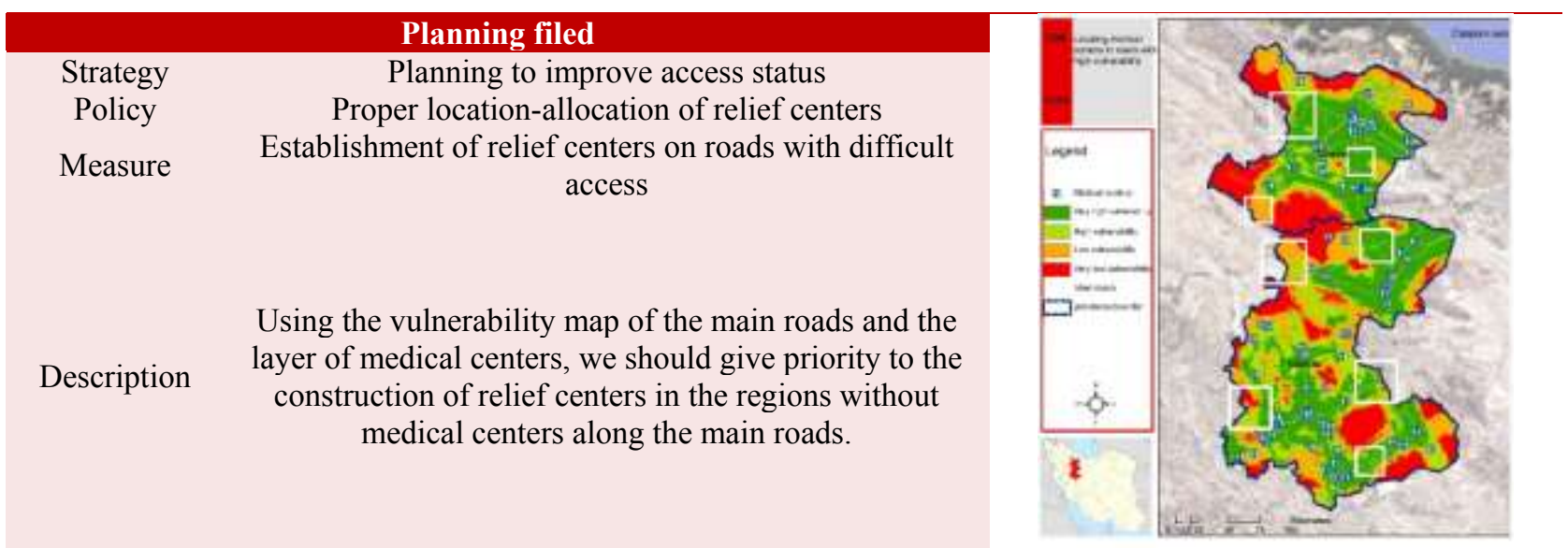

Map 11. Proper location-allocation of relief centers 
striving to improve the situation of relief centers. In this regard, the regions with a low density of relief centers are identified and are given priority for the construction of relief and treatment centers.

In the third program which aimed at dealing with the risk of hazards, the necessary strategies and policies are presented to control the postincident situation and prevent hasty decisions. To this end, two maps of incident risk and vulnerability were combined in the GIS environment and a crisis map was obtained. A different impact factor was applied for each map due to its importance in aggravating the risk and making the situation critical. As depicted in Map 12, most of central Qazvin, as well as the southwestern and northeastern Markazi province are highly susceptible to the post-earthquake fire crisis. These areas also had unfavorable conditions in both hazard and vulnerability maps; therefore, it seems necessary to increase preparedness and develop strategic plans to deal with and mitigate the fires and subsequent damages in these areas.

As shown in Map 12, the critical areas are located in the center of Qazvin province, as well as northeast and southwest of Markazi province. Each of these three areas is presented with postincident problems, such as the shortage of medical centers, destruction of infrastructure, road obstruction, as well as broken oil and gas pipelines. Nonetheless, since the third program aimed to deal with the incident, it seems necessary to perform a more thorough assessment and impose some limitations on the area. The central

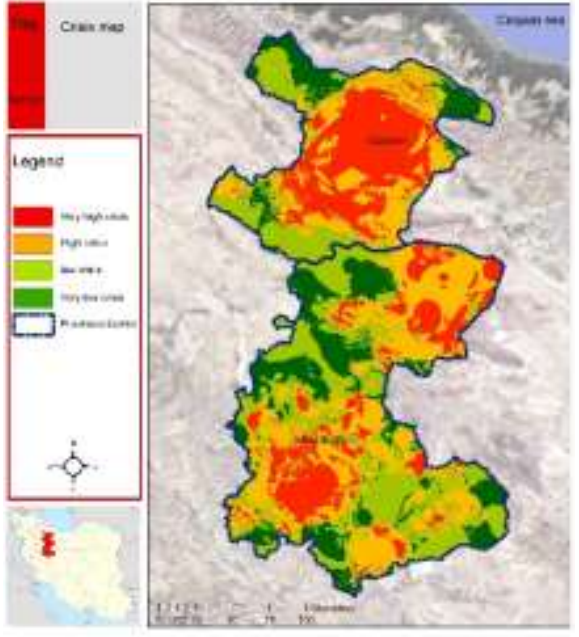

Map 12. Crisis region of Qazvin province was selected for the assessment and planning to cope with the incident and reconstruct. The required maps for this area were prepared based on the factors obtained in the DSD table of the first and second programs. According to Map 13, in the central part of Qazvin province, access to fire stations is in good condition, and the distance is maximized in the northwestern and southwestern parts.

Table 7 separately examines the strengths and weaknesses of all factors affecting postearthquake fires.

In this regard, in the selected area, according to the analysis of the SWOT table, the presented strategies were explained in order of importance obtained from the questionnaire. They are mentioned in order of priority in different fields:

In the field of planning: 1. using experts to investigate and identify crack formed on oil and gas pipelines, 2. using experts to repair electricity networks, 3. Planning to accommodate the injured in areas far from gas and oil pipelines. In the offensive filed: 1 . equipping medical centers in the disaster-affected area during and after the incident, 2. preventing the occurrence of secondary effects and disruption of normal life by immediate repair of roads in the early days, 3 . firefighters' use of fast fire extinguishing methods.

In the defensive field: 1.use of the relief workers from the neighboring provinces, 2 . controlling the direction of fire movement by predicting the fuel source of the fire and eliminating it, 3. maintaining a distance between relief centers and electricity/gas networks. In the crisis field: 1 . the construction of special routes

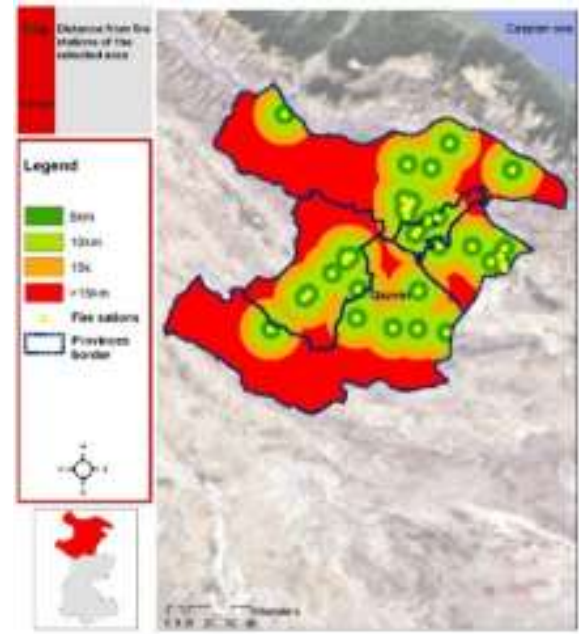

Map 13. Distance from fire stations in the selected area 
to be used in times of crisis for easy access to the incident site, 2. the use of volunteer forces to extinguish the fire, 3. temporary closure of industrial units, factories, and high-risk industries that are located in the vicinity of the incident site.

Due to the priority of strategic plans to deal with fires, it is necessary to strengthen infrastructure and preparedness in various fields. The fourth plan aimed to reconstruct, along with sustainable development in social, economic, physical, and environmental dimensions after the occurrence of the post-earthquake fire. Based on the selected region, numerous damages will be inflicted on different parts of Qazvin and Markazi following the occurrence of the post-earthquake fire and its persistence for a long time.

In addition to physical and objective damages, society is also affected by intangible damages which are not visible in the early stages of reorganization and reconstruction; nevertheless, their adverse consequences will be imposed on society. Therefore, in this program, it is necessary to devote assiduous attention to the tangible and intangible aspects of damages in order to formulate a principled reconstruction plan. Table 8 presents the SWOT table for the reconstruction program taking into account the indicators obtained in previous programs, the conducted studies, and the

Table 7. Analysis of strengths, weaknesses, opportunities, and threats

\begin{tabular}{|c|c|c|c|c|c|}
\hline sk fac & & Strength (S) & Weakness (W) & Opportunity (O) & Threat (T) \\
\hline Infrastructure & $\begin{array}{l}\text { Power, } \\
\text { gas, and } \\
\text { oil lines }\end{array}$ & $\begin{array}{l}\text { S1: The alignment of } \\
\text { gas and oil pipelines and } \\
\text { their non-dispersion } \\
\text { keep other areas away } \\
\text { from danger. }\end{array}$ & $\begin{array}{l}\text { W1: Exposure of } \\
\text { power lines to } \\
\text { fire, especially in } \\
\text { critical areas }\end{array}$ & $\begin{array}{c}\text { O2: Ability to } \\
\text { immediately } \\
\text { strengthen power lines } \\
\text { in the early days after } \\
\text { the accident }\end{array}$ & $\begin{array}{c}\text { T3: Invisible } \\
\text { fractures in gas } \\
\text { and oil pipelines }\end{array}$ \\
\hline $\begin{array}{l}\text { Relief and } \\
\text { Rescue }\end{array}$ & $\begin{array}{l}\text { Military } \\
\text { centers }\end{array}$ & $\begin{array}{l}\text { S8: Existence of law } \\
\text { enforcement } \\
\text { organization to establish } \\
\text { security }\end{array}$ & $\begin{array}{l}\text { W6: Insufficient } \\
\text { control of the } \\
\text { environment } \\
\text { despite law } \\
\text { enforcement }\end{array}$ & $\begin{array}{l}\text { O7: Use of law } \\
\text { enforcement centers in } \\
\text { surrounding provinces }\end{array}$ & $\begin{array}{l}\text { T8: Low number } \\
\text { of military } \\
\text { forces increases } \\
\text { insecurity. }\end{array}$ \\
\hline Environmental & $\begin{array}{l}\text { Population } \\
\text { density }\end{array}$ & $\begin{array}{l}\text { S11: Low population in } \\
\text { the northern areas }\end{array}$ & $\begin{array}{l}\text { W10: Large } \\
\text { population in } \\
\text { high-risk areas } \\
\text { and housing } \\
\text { difficulties }\end{array}$ & $\begin{array}{l}\text { O12: Relocating } \\
\text { populations based on } \\
\text { different priorities }\end{array}$ & $\begin{array}{c}\text { T13: The } \\
\text { possibility of } \\
\text { increased theft } \\
\text { and looting in } \\
\text { low-density cities } \\
\text { due to solitude }\end{array}$ \\
\hline Social & $\begin{array}{l}\text { Business } \\
\text { centers }\end{array}$ & $\begin{array}{c}\text { S15: Economic } \\
\text { prosperity in various } \\
\text { fields in the critical area }\end{array}$ & $\begin{array}{c}\text { W13: } \\
\text { Concentration of } \\
\text { all important and } \\
\text { large commercial } \\
\text { centers in the } \\
\text { center of the } \\
\text { province }\end{array}$ & $\begin{array}{l}\text { O16: Revitalizing } \\
\text { commercial centers in } \\
\text { the provincial capital } \\
\text { after a fire to revitalize } \\
\text { the economy and } \\
\text { livelihood }\end{array}$ & $\begin{array}{l}\text { T17: Sudden } \\
\text { economic } \\
\text { downturn in the } \\
\text { event of fire } \\
\text { occurrence in } \\
\text { business centers }\end{array}$ \\
\hline $\begin{array}{l}\text { Decision } \\
\text { making }\end{array}$ & $\begin{array}{l}\text { Upstream } \\
\text { planning } \\
\text { system }\end{array}$ & $\begin{array}{l}\text { S18: Existence of Red } \\
\text { Crescent and Crisis } \\
\text { Management }\end{array}$ & $\begin{array}{c}\text { W14: } \\
\text { Management } \\
\text { weakness and } \\
\text { confusion when } \\
\text { an incident occurs }\end{array}$ & $\begin{array}{l}\text { O17: Attention of } \\
\text { various national and } \\
\text { international } \\
\text { organizations to fire } \\
\text { occurrence }\end{array}$ & $\begin{array}{l}\text { T18: Inadequate } \\
\text { extra-regional } \\
\text { policies in risk } \\
\text { management } \\
\text { planning }\end{array}$ \\
\hline Water sources & Dams & $\begin{array}{c}\text { S21: The incoming } \\
\text { water is more than } 33 \\
\text { billion cubic meters per } \\
\text { year }\end{array}$ & $\begin{array}{l}\text { W17: There is } \\
\text { only one dam in } \\
\text { the entire critical } \\
\text { area. }\end{array}$ & $\begin{array}{l}\text { O20: Possibility to } \\
\text { store water for } \\
\text { emergency use }\end{array}$ & $\begin{array}{l}\text { T22: } \\
\text { Impossibility of } \\
\text { water reaching } \\
\text { further areas } \\
\text { from this water } \\
\text { reservoir }\end{array}$ \\
\hline
\end{tabular}


recognition of the study area.

It is noteworthy that for the development of strategies, apart from the table of conformity of external and internal factors, a questionnaire with a Likert scale was completed by experts to confirm the obtained strategies and their importance. These strategies in the field of postincident reconstruction are listed below in order of importance based on the analysis of the questionnaire:

1. strengthening power transmission lines, especially in central and densely populated areas, 2. improving the condition of oil transmission pipelines in the study area, 3. strict measures for construction projects to comply with the third issues of national regulations, 4. protection of fire stations, especially in densely populated cities, 5 . correct and dynamic planning for training and presenting pre-determined maps for hazardous conditions in certain provinces, 6. improving the efficiency of water reservoirs, especially those located at higher altitudes than the designated area, 7. considering relief and service provision centers, 8. developing and organizing consistent with access network to provide relief services considering the active faults and high probability of incidents, 9. enacting suitable laws to locate industrial cities and factories base on crisis map, 10. using the management tools of the incident command system in order to achieve coordination and integration.

In order to achieve the goals of this program, it seems necessary to take some measures to implement the stated strategies, some of which are described in this article:

1. The experts' regular inspection of high-risk routes and gas storage places, 2. the use of modern technologies to increase the resilience of gas pipelines, 3. the need to use a sufficient number of gas shut-off valves at appropriate intervals and their maintenance, 4. equipping power transmission lines with alarm system and automatic power outage system, 5 . the placement of fuel materials in special tanks, insulation, and

Table 8. Analysis of strengths, weaknesses, opportunities, and threats of the fourth program (post-disaster reconstruction)

\begin{tabular}{|c|c|c|c|c|}
\hline $\begin{array}{l}\text { Factors affecting } \\
\text { reconstruction }\end{array}$ & Strength (S) & Weakness (W) & Opportunity (O) & Threat (T) \\
\hline $\begin{array}{l}\text { Infrastructure and } \\
\text { buildings }\end{array}$ & $\begin{array}{l}\text { S7: Existence of experienced } \\
\text { specialists in the province } \\
\text { for repair and reconstruction } \\
\text { of gas pipelines and facilities }\end{array}$ & $\begin{array}{l}\text { W4: Reconstruction } \\
\text { is time-consuming } \\
\text { and costly }\end{array}$ & $\begin{array}{l}\text { O5: Possibility of } \\
\text { assigning special routes } \\
\text { for times of crisis }\end{array}$ & $\begin{array}{l}\text { T2: Rapid } \\
\text { reconstruction } \\
\text { regardless of quality } \\
\text { and criteria }\end{array}$ \\
\hline Environmental & S9: No vegetation dispersion & $\begin{array}{l}\text { W5: Extensive } \\
\text { damage to the } \\
\text { environment in case } \\
\text { of fire }\end{array}$ & $\begin{array}{l}\text { O9: being located in the } \\
\text { central region of the } \\
\text { country }\end{array}$ & $\begin{array}{l}\text { T4: The gradual } \\
\text { process of drought } \\
\text { and global warming }\end{array}$ \\
\hline Economic & $\begin{array}{l}\text { S10: Existence of a growing } \\
\text { economy with a young and } \\
\text { job-seeking workforce }\end{array}$ & $\begin{array}{c}\text { W7: Financial } \\
\text { constraints on } \\
\text { development credits }\end{array}$ & $\begin{array}{l}\text { O11: Increasing trend } \\
\text { of allocating budgets } \\
\text { for the reconstruction } \\
\text { of damaged regions }\end{array}$ & $\begin{array}{l}\text { T5: The economic } \\
\text { situation of the region } \\
\text { is endangered due to } \\
\text { the density of } \\
\text { commercial units and } \\
\text { agricultural lands. }\end{array}$ \\
\hline Social & $\begin{array}{l}\text { S13: Existence of pre- } \\
\text { incident NGO relief groups }\end{array}$ & $\begin{array}{l}\text { W10: Weakness of } \\
\text { planning and } \\
\text { preparation system } \\
\text { of the two } \\
\text { provinces }\end{array}$ & $\begin{array}{l}\text { O15: Ability to use } \\
\text { young and educated job } \\
\text { seekers }\end{array}$ & $\begin{array}{c}\text { T6: Pessimistic } \\
\text { attitudes toward } \\
\text { government structures }\end{array}$ \\
\hline $\begin{array}{l}\text { Administrative / } \\
\text { Political }\end{array}$ & $\begin{array}{c}\text { S15: Optimal conditions of } \\
\text { the province for integrated } \\
\text { development }\end{array}$ & $\begin{array}{l}\text { W12: Lack of } \\
\text { coordination among } \\
\text { the organizations } \\
\text { involved in the } \\
\text { reconstruction }\end{array}$ & $\begin{array}{l}\text { O18: Ability to } \\
\text { increase interactions } \\
\text { with certain provinces }\end{array}$ & $\begin{array}{l}\text { T11: Discontinuation } \\
\text { of political support } \\
\text { during the } \\
\text { reconstruction period }\end{array}$ \\
\hline
\end{tabular}


their proper restraint with structural elements, 6 . the concentration of high-risk units and formation of industrial cities to prevent simultaneous fire ignition in several areas, 7. equipping high-risk areas with fire warning devices, 8. the replacement of oil and gas pipelines which are in the vicinity of active faults, 9. strengthening access by creating special routes for ambulances within and between cities and widening existing roads, 10. integration of parallel organizations to reduce costs and increase capabilities.

\section{Discussion and Conclusion}

Post-earthquake fire as one of the secondary effects of earthquakes can cause more casualties and damages from the ground motion itself in the absence of necessary predictions and preparations. As evidenced by the obtained results, according to the hypotheses and experts' opinion, the central parts of Qazvin province and the northeastern and southwestern regions of Markazi province are exposed to the highest severity of vulnerability. Moreover, it was indicated that vegetation expansion in the vicinity of high-risk centers and observing fire safety measures in new constructions can reduce the likelihood of postearthquake fire.

Furthermore, the central and eastward areas in Qazvin province, as well as the northeastern and southwestern areas in Markazi province, run the highest risk of post-earthquake fire. Therefore, some strategies, such as strengthening access networks and water resources management, can reduce the damages and vulnerability after the occurrence of fire. Based on the integration of risk and vulnerability maps, the majority of central Qazvin, as well as the northeastern and southwestern Arak are the critical areas in terms of probability of occurrence and spread of postearthquake fire; consequently, the high sensitivity of these areas requires assiduous attention.

In this regard, in the event of an earthquake, the following fire can be prevented by the promotion of managerial attitudes, the devotion of special attention to these sensitive areas, and provision of such practical solutions as the use of specialized forces in the early hours after the incident so as to identify and control the cause of the fire, predict the fuel source, and eliminate. Moreover, in order to improve the conditions of the society during post-fire reconstruction, the resilience of peoples to future incidents can be increased by the use of management tools of the incident command system in order to ensure coordination among the relief workers. Therefore, it is indispensable to develop some strategies to reduce the likelihood of occurrence and vulnerability, coping methods, and preparedness for reconstruction. In general, the results of the current study indicated that policies and strategies designed for the risk reduction of post-earthquake fire must be based on risk maps and consistent with the subsequent hazards and damages. Therefore, the assessment of the relative risk of post-earthquake fire can be regarded as one of the major steps in future regional planning for land use allocation and risk reduction.

\section{Acknowledgments}

We would like to thank Dr. Sharif Motawaf for guiding us in conducting this research and also to all the experts, professors and students who worked with us during the research process.

\section{Conflict of Interests}

Authors have no conflict of interests.

\section{References}

1. Chen S, Lee GC, Shinozuka M. Hazard mitigation for earthquake and subsequent fire. ANCER Annual Meeting: Networking of Young Earthquake Engineering Researchers and Professionals, New York, USA; 2004.

2. Botting R, Buchanan A. Building design for fire after earthquake. 12th World Conference on Earthquake Engineering. Christchurch, New Zealand, Oceania; 2000.

3. Bektash N, Gezechi S. Assess and manage fire risk after an earthquake. $5^{\text {th }}$ International Congress on Civil Engineering Architecture and Urban Development, Tehran, Iran; 2017. [In Persian].

4. Scawthorn C. Fire following earthquake-analysis and mitigation in North America. Proceedings of the International Symposium on Engineering Lessons Learned from the 2011, Tokyo, Japan; 2012. P. 913-6.

5. Yavari A. The role of HSE management system in post-earthquake fires. 2nd National Conference on Safety Engineering and HSE Management, Tehran, Iran; 2008. [In Persian].

6. Heidari R, Alavizade SA, Javidifar M. Prevention of fire after an earthquake in Tehran. First International Conference \& Fourth National Conference on Urban Fire Service \& Safety, Tehran, Iran; 2019. [In Persian]. 
7. Li J, Wang Y, Chen H, Lin L. Risk assessment study of fire following an earthquake: a case study of petrochemical enterprises in China. Natural Hazards Earth Syst Sci 2014; 14(4): 891-9.

8. Kherdast A. Determining and prioritizing the factors affecting the capability of fire stations in post-earthquake fires, a case study of stations covered by District 19 of Tehran Municipality. The First National Conference on Social Problems, Ardabil, Iran; 2017. [In Persian].

9. Zare M. Assessing the safety of Tehran against fire after the earthquake. Third National Conference on Urban Fire Service \& Safety, Tehran, Iran; 2018. [In Persian].

10. Nazari M, Hasanlou HR, Damghaninasab V. Postearthquake fire management. Second National Conference on Urban Fire Service \& Safety, Tehran, Iran; 2017. [In Persian].

11. Mizuno H. On outbreak of fires in earthquakes. Kyoto, Japan: Department of Architecture, Kyoto University; 1978.

12. Zolfaghari M, Peghaleh E, Golmoradi L, Nasirzadeh GH. Fire following earthquake modelling. Probabilistic ignition model for building stock. The $14^{\text {th }}$ World Conference on Earthquake Engineering, Beijing, China; 2008.

13. Esposito S. Systemic seismic risk analysis of gas distribution network. Naples, Italy: Universitita Di Napoli Federico; 2011.

14. Yildiz SS, Karaman H. Developing a physics-based model for post-earthquake ignition. 9th International ISCRAM Conference, Vancouver, Canada; 2012.

15. Planning of Qazvin and Markazi provinces. Qazvin: Qazvin and Markazi Province Budget Program Organization; 2005. P. 77-139. [In Persian].

16. Lee S, Davidson R, Ohnishi N, Scawthorn C. Fire following earthquake-Reviewing the state-of-theart of modeling. Earthquake Spectra 2008; 24(4): 933-67.

17. Doosti A, Mohtat N, Asadian Zargar N. Physical recovery plan for a possible earthquake in Tehran and Alborz province, (vulnerability reduction and preparation). Dis Prev Manag Knowl 2015; 5(3): 210-20. [In Persian].

18. Eidinger JM. Fire following earthquake - flex hose. 13th World Conference on Earthquake Engineering, Vancouver, Canada; 2004. P. 1-6.

19. Karppi I, Kokkonen M, Lähteenmäki-Smith K. SWOT-analysis as a basis for regional strategies. Stockholm, Sweden: Nordregio; 2001.

20. Kelly EJ, Tell RN. A method for evaluating fire after earthquake scenarios for single buildings. Handout for DOE Natural Phenomena Hazards Workshop, Washington, D.C, USA; 2011. P. 1-7.

21. Scawthorn C. Fire following earthquake. Fire Saf Sci 1986; 1(4): 971-4.

22. Scawthorn C. Water supply in regard to fire following earthquake. Pacific Earthquake Engineering Research Center, Berkeley, California; 2011. P. 5-7. 